\title{
Macroinvertebrate communities associated with littoral zone habitats and the influence of environmental factors in Malilangwe Reservoir, Zimbabwe
}

\author{
T. Dalu ${ }^{(1,2) \star}$, B. Clegg $^{(3)}$, T. Nhiwatiwa ${ }^{(1)}$
}

Received April 17, 2012

Revised August 6, 2012

Accepted August 7, 2012

Key-words:

Macroinver-

tebrates,

diversity,

Malilangwe

reservoir,

macrophyte

cover,

conductivity, water level

\section{ABSTRACT}

The aim of our study was to investigate macroinvertebrate communities so as to understand factors and processes structuring macroinvertebrate communities in a small reservoir, Malilangwe reservoir over seven months (April to October). Sampling was performed by active sweep netting and searching soil sediments. Water temperature, conductivity, dissolved oxygen, $\mathrm{pH}$, ammonia, nitrogen, phosphorus, chemical oxygen demand and macrophyte cover were determined. In total, forty-two macroinvertebrate families belonging to 10 orders were identified amongst 13 macrophyte species and sediments. Thiaridae and Physidae (Mollusca) were the dominant and most abundant taxa $(57.71 \%)$ and there were followed by the Hemiptera (27.31\%). High indices for sites 1 to 3 for the Simpsons index, the Shannon-Weaver index and evenness were recorded, while low indices were observed for sites 4 to 5 , with significant differences being observed among the study site using the Kruskal-Wallis ANOVA test $(p<0.05)$. Redundancy Analysis revealed that among environmental factors, hydrologically linked parameters such as conductivity, water level and macrophyte cover had the strongest influence on macroinvertebrate distribution.

\section{RÉSUMÉ}

Les communautés de macro-invertébrés associées aux habitats de la zone littorale et l'influence des facteurs environnementaux dans le réservoir Malilangwe, Zimbabwe

Mots-clés : Le but de notre étude était d'étudier les communautés de macro-invertébrés de macro-invertébrés, manière à comprendre les facteurs et les processus qui structurent ces combiodiversité, munautés dans un petit réservoir, réservoir Malilangwe, au cours de sept mois réservoir Malilangwe, macrophytes, conductivité (avril à octobre). L'échantillonnage a été effectué par balayage actif et prospection des sédiments. La température de l'eau, la conductivité, l'oxygène dissous, le $\mathrm{pH}$, l'ammoniac, l'azote, le phosphore, la demande chimique en oxygène et la couverture de macrophytes ont été déterminés. Au total, quarante-deux familles de macro-invertébrés appartenant à 10 ordres ont été identifiées dans les 13 espèces de macrophytes et les sédiments. Thiaridae et Physidae (Mollusca) étaient les taxons dominants et les plus abondants $(57,71 \%)$, suivis par les Hemiptera $(27,31 \%)$. Des valeurs élevées pour les sites de 1 à 3 de l'indice de Simpson, de

(1) Department of Biological Sciences, University of Zimbabwe, PO Box MP167, Mt. Pleasant Harare, Zimbabwe

(2) Zoology and Entomology, Rhodes University, PO Box 94, Grahamstown 6140, South Africa

(3) Malilangwe Wildlife Reserve, P. Bag 7085, Chiredzi, Zimbabwe

* Corresponding author: dalutatenda@yahoo.co.uk 
l'indice de Shannon-Weaver et de la régularité ont été observées, tandis que des indices faibles ont été observés pour les sites 4 à 5 , avec des différences significatives observées entre les sites d'étude en utilisant le test ANOVA de Kruskal-Wallis $(p<0,05)$. L'analyse de redondance a révélé que parmi les facteurs environnementaux, les paramètres liés à l'hydrologie tels que la conductivité, le niveau de l'eau et la couverture de macrophytes ont la plus forte influence sur la distribution des macro-invertébrés.

\section{INTRODUCTION}

Macroinvertebrates are the most diverse and abundant organisms in freshwater aquatic systems and are a key component of aquatic ecosystem function (Kratzer, 2002). Macroinvertebrates distribution and community is strongly dependent on the composition and structure of vegetation and macroinvertebrates are recognized as an essential food source for juvenile fish and amphibians in aquatic systems (Takhelmayum and Gupta, 2011). Lakes with well-developed macrophyte communities are characterised by more diverse communities of zooplankton, benthos and fish (Kouamé et al., 2011). Some species of the major secondary producers such as rotifers, cladocerans and insect larvae are commonly found in both pelagic and vegetated areas, whereas others are exclusively found within vegetation stands (Curtis, 1991; Skoroszewski and de Moor, 1999; Rocha-Ramirez et al., 2007; Kouamé et al., 2011).

Diverse invertebrate communities exist among the submersed vegetation of ponds, pools and lakes. The abundance of phytophilous invertebrates in an aquatic ecosystem is defined by many factors including macrophyte morphology, substrate texture and epiphytic algal growth, community composition and defensive chemicals (Hann, 1995; Skoroszewski and de Moor, 1999; Kratzer, 2002; Albertoni et al., 2007).

Water levels fluctuations occur naturally in lakes and reservoirs as a result of seasonal imbalances between the amounts of water entering via inflow, precipitation, runoff and/or groundwater inputs and water leaving the lake via evaporation, seepage and/or outflow (Zohary and Ostrovsky, 2011). Lakes and reservoirs fluctuate seasonally between maximum levels during the rainy season and minimum levels usually at the end of the dry season in tropical regions such as Zimbabwe. Extreme or untimely water level fluctuations can have undesirable effects on the ecosystems (Bond et al., 2008). Human exploitation of water resources can lead to increased annual and inter-annual water level fluctuations, at times, far beyond natural amplitudes and/or irrespective of the natural hydrological cycle. A range of natural features of the water level regime are often impacted, not only the amplitude of fluctuation but also the timing of the minimum and maximum water levels and the rates of water level increase and decline (Gasith and Gafny, 1990; Zohary and Ostrovsky, 2011).

Aquatic macroinvertebrate assemblages and communities can act as good indicators of the prevailing hydrological regime and water quality in aquatic systems. Several studies on macroinvertebrates, focused on community composition or association with the plant community, have been carried out on large water bodies in Zimbabwe such as Lake Kariba (Begg, 1970; Machena and Kaustky, 1989; Mhlanga and Siziba, 2006; Phiri et al., 2011a, 2011b). This current study is the first to be carried out on the Malilangwe Reservoir macroinvertebrate community. The aim was to characterize the freshwater macroinvertebrate communities found in the littoral zones of the reservoir to assess if monthly/seasonal changes in environmental parameters have impacts on macroinvertebrate communities. The role of environmental factors on taxon richness, diversity, relative abundance, distribution and dominance of macroinvertebrates was also investigated. 


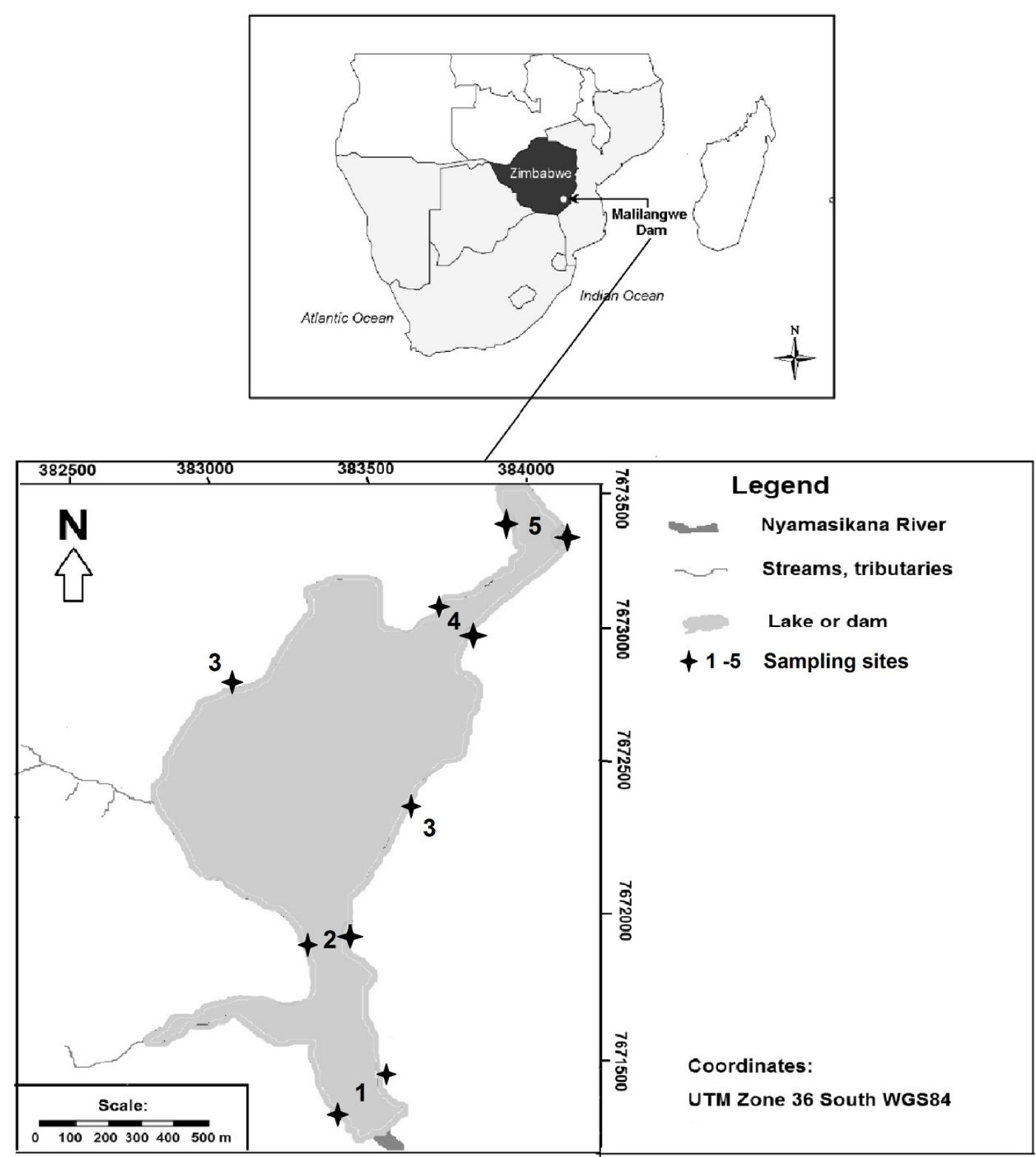

Figure 1

Location of littoral zone sampling sites around Malilangwe Reservoir, Zimbabwe.

\section{STUDY AREA}

Malilangwe Reservoir is located in the Chiredzi District, south-eastern lowveld region of Zimbabwe $\left(20^{\circ} 58^{\prime} 21^{\circ} 02^{\prime} \mathrm{S}, 31^{\circ} 47^{\prime} 32^{\circ} 01^{\prime} \mathrm{E}\right)$ (Figure 1). Mean annual rainfall calculated from a 56 year record (1951-2010) collected at Malilangwe Head Quarters is approximately $562 \mathrm{~mm}$, but is very variable both within and between seasons. Approximately $84 \%$ of rainfall occurs between November and March (Clegg, 2010). The average annual rainfall for Malilangwe is extremely erratic and the lowveld area is prone to drought (Davy, 2005). Temperatures are high with most daily maxima in excess of $32{ }^{\circ} \mathrm{C}$ throughout the year and peak temperatures during hot spells in the summer often over $45^{\circ} \mathrm{C}$. Winters are generally cool, with temperatures ranging from $5-26{ }^{\circ} \mathrm{C}$ with frost virtual absent (Traill, 2003). The annual average evaporation has been estimated at ca. 2000 mm (Kelly and Walker, 1976). 
Malilangwe Reservoir is an impounded river, created in 1964 and is used as a water supply for the Malilangwe wildlife reserve community. It is a gravity section masonry dam with a surface area of 211 hectares and maximum volume of $12 \times 10^{6} \mathrm{~m}^{3}$ at full capacity with volume development of 0.95 . The maximum depth of the reservoir is $14.30 \mathrm{~m}$, mean depth is $4.54 \mathrm{~m}$, shoreline length is $9415 \mathrm{~m}$ with a shoreline development of 1.83 . Flanked by rocky hills on most of its sides, the Reservoir has a rocky substrate with few sandy bays. The reservoir has few marginal plants including Azolla filiculoides, Panicum repens, Ludwigia stolonifera, Potamogeton sp., Schnoeplectus corymbosus, Cyperus sp. and Phragmites mauritanus (Barson et al. , 2008; Dalu, unpub. data). Five sampling sites were selected based on differences in vegetation type and cover, substrate type, position in relation to the inflow and outflow points. Two stations were selected for each site, on the eastern and western costs of the reservoir. Site 1 was located in the deepest part and next to the dam wall (depth $=1.05$ eastern shore and 0.60 western shore). Site 2 was located between the two hills (depth $=0.85$ eastern shore and 0.35 western shore), site 3 was located on the littoral zones of the open waters (depth $=$ 0.60 eastern shore and 0.45 western shore), site 4 , was the point where the reservoir narrows into a river channel (depth $=0.25$ eastern shore and 0.30 western shore) and site 5 was located where the Nyamasikana River enters the reservoir (depth $=0.30$ eastern shore and 0.50 western shore).

\section{MATERIALS AND METHODS}

\section{>BASIC WATER QUALITY MEASUREMENTS}

Integrated water sample along the water column was collected in the morning at each site on a monthly basis (April to October) with measurements of $\mathrm{pH}$, conductivity, total dissolved solids (TDS), water temperature and dissolved oxygen (DO) done using a $\mathrm{pH}$, conductivity and DO meter (HACH, LDO, Germany). Water transparency was measured using a Secchi disk. Chemical oxygen demand (COD), nitrogen and nitrates and total and reactive phosphorus were determined using standards methods from Environmental Protection Agency (EPA), Hach and Standard Methods. Water level was measured from the dam spillway level to the water surface on a monthly basis using a tape measure and water volume estimated using calculations by Thackeray and Leuci (unpub. data) and Dalu (unpub. data). The seasonal pattern of stratification of the water column was determined by measuring water temperature and dissolved oxygen at $1 \mathrm{~m}$ depth intervals using an oxygen meter (LDO HQ20, HACH). Measurements were done once a month throughout the three seasons; hot-wet (April), cool-dry (May to August) and hot-dry (September to October) from the deepest point of the reservoir (Site 1) and it should be noted that the sampling strategy did not consider spatial variations due to time limitations, hence one site was selected. The macrophyte flora and physical character of the area was surveyed by wading and by boat. Wading was done in zigzag manner across the littoral zone length, frequently investigating all the macrophyte species present. At sites where the water was too deep to wade, a boat was used. Percentage macrophyte cover of all species present within transect was recorded. Identification of the macrophytes were done up to species level where possible using field identification guides by Sainty and Jacobs 1988) and also with the help of a local experts such as Bruce Clegg and Mark Hyde and Bart Wursten of Zimbabwe Flora (www.zimbabweflora.co.zw).

\section{> MACROINVERTEBRATE SAMPLING}

Sampling was carried out at the end of each month for the five selected sites but no samples were collected in May for site 5 due to presence of a large herd of hippos. Macroinvertebrates were sampled semi-quantitatively using a nylon hand net (mesh size $500 \mu \mathrm{m}$, dimension $30 \times 30 \mathrm{~cm}$ ) with an aluminium rim and a handle which could be extended to allow sampling distance of up to $1.5 \mathrm{~m}$. At each sampling station, macroinvertebrates were 
collected by submerging the sampling net and sweeping a demarcated $10 \mathrm{~m}$ transect. This involved walking through the water dragging the net through the macrophyte vegetation. The kick-net was carefully lifted out of the water to prevent the escape of agile animals.

Benthic macroinvertebrates were collected at each station using a mud grabber along the littoral areas. The benthic sample was collected by pouring and washing the sample through a $1.5 \mathrm{~mm}$ mesh sieve and removing organisms for identification and counting. For each site, macroinvertebrates collected from the two littoral zones (eastern and western shores of the reservoir) and the two benthic samples were then pooled to constitute a single sample. The samples were preserved in a $70 \%$ alcohol solution in $250 \mathrm{~mL}$ plastic containers for identification to family level using several keys, including Gooderham and Tsyrlin (2002) and Gerber and Gabriel (2002a, 2002b). Although species level identification is desirable, family level identification is often the only achievable for studies in Sub-Saharan Africa region. Even though information is lost due poor taxonomic resolution, several studies have demonstrated that family level classification for macroinvertebrates can produce meaningful results (Bailey et al., 2001; Kratzer, 2002; Nhiwatiwa et al., 2009; Kouamé et al., 2011). Relative abundance (\%) was calculated as the number of one macroinvertebrate taxa per total number of macroinvertebrates of a given site.

\section{DATA ANALYSIS}

\section{> PHYSICOCHEMICAL CHARACTERISTICS}

Analysis of physicochemical characteristics between sampling stations for the study months was carried out using SysStat ver. 12 and the data followed an ordinal rating, which violates various ANOVA assumptions. Hence, the data was not normal as confirmed by the ShapiroWilk normality test. Therefore, the non-parametric test, Kruskall Wallis $(p<0.05)$ was carried out to test the differences in physicochemical characteristics between sampling stations after pooling all values for each site so as to assess if they were any significant differences between the study sites $\left(H_{0}\right.$ : no difference between five sampling points) using SysStat ver. 12 (Systat, 2007).

\section{> DIVERSITY INDICES}

Two main indices were used, the Shannon-Weaver index (H) (Shannon and Weaver, 1949) and the Simpson's index (D) (Simpson, 1949) to analyse the macroinvertebrate communities collected during each sampling occasion for the study sites:

$$
\begin{aligned}
& H=-\sum p_{i} \ln p_{i} \\
& D=\sum[n(n-1) / N(N-1)] .
\end{aligned}
$$

The Simpson's index was used to analyse for dominance whilst the Shannon-Weaver was used to estimate richness and diversity. The Evenness $(E)$ is a measure of how similar the abundance of different taxa is. A Hutchenson (1970) criterion for the comparison of the diversity values was used to express differences between the values of diversity of sites. The null hypothesis $\left(H_{0}\right): H_{1}^{\prime}=H_{2}^{\prime}$ (the diversity of site one is statistically equal to that of site two). The $t$ value is calculated as:

$$
t=\frac{H_{1}^{\prime}-H_{2}^{\prime}}{\sqrt{S_{H_{1}^{\prime}}^{2}+S_{H_{2}^{\prime}}^{2}}} \cdot
$$




\section{> ASSESSMENT OF TAXA DOMINANCE AND DIVERSITY}

Rank abundance is a measure of biodiversity and the curves are important as they are a measure of evenness as they are used to study the distribution of abundance among taxa in a sample. Rank Abundance Analysis for the ten most abundant macroinvertebrate taxa was carried out using PC-ORD for Windows 5 (2006) to assess the distribution of abundance among taxa in the samples.

\section{> ASSESSMENT OF THE INFLUENCE OF ENVIRONMENTAL FACTORS ON MACROINVERTEBRATE COMMUNITIES}

To determine whether to use linear or unimodal methods for the analysis, Detrended Canonical Correspondence Analysis (DCCA) was used. The lengths of the gradients were examined and since the longest gradient was shorter than 3.0, a linear constrained method was deemed the most appropriate choice (ter Braak, 2002). Redundancy Analysis (RDA) is a constrained linear ordination method based on significant $(p<0.05)$ forward selected environmental variables. A total of 499 Monte Carlo Permutations were used for RDA analysis. The software Canoco (ver. 4.5) was used for the analysis (ter Braak, 2002).

\section{RESULTS}

\section{> ENVIRONMENTAL VARIABLES}

Water level at the beginning of April was $9.42 \mathrm{~m}$ or $7.02 \times 10^{6} \mathrm{~m}^{3}$ in volume and in October; it was $8.12 \mathrm{~m}$ or $4.82 \times 10^{6} \mathrm{~m}^{3}$ in volume. Water level decreased at an average of $18.57 \mathrm{~cm}$ depth per month which corresponds to about $3.14 \times 10^{5} \mathrm{~m}^{3}$ for the reservoir from April to October 2011 , with a total of $1.3 \mathrm{~m}$ depth or $2.19 \times 10^{6} \mathrm{~m}^{3}$ of water being lost due to drawdown and evaporation (Table I). June recorded the least decrease in water level of $9 \mathrm{~cm}$ whilst October had the highest decreases $(25 \mathrm{~cm})$.

Table I summarizes the mean values of environmental variables in the Malilangwe reservoir for study period. Secchi disk transparency was the unique variable exhibiting significant variability amongst the study sites $(p<0.05)$ whilst other environmental parameters were not spatially significantly different $(p>0.05)$. Secchi disk readings ranged between $0.2-1.7 \mathrm{~m}$. Dissolved oxygen (DO) values increased between May to August before dropping in September to October. Well oxygenated water was found throughout the cool-dry season $\left(7-9 \mathrm{mg} \cdot \mathrm{L}^{-1}\right)$ due to complete mixing of the water body (turn-over) while the reservoir was stratified during the hot-wet and -dry season. Low DO levels of up $2 \mathrm{mg} \cdot \mathrm{L}^{-1}$ were recorded during September to October for sites 1 and 2 bottom waters. Lowest water temperature occurred from May to September after which there was rapid increase. Water temperatures decreased from April to October with low temperature average being recorded in June $\left(19.3^{\circ} \mathrm{C}\right)$. Temperatures then increased from June to September $\left(27.6^{\circ} \mathrm{C}\right)$. Highest temperatures were recorded in October $\left(28.4^{\circ} \mathrm{C}\right)$ and lowest in June $\left(18.8^{\circ} \mathrm{C}\right)$ (Table I).

Ammonia and total nitrogen decreased during the cool-dry season, during May to July as it was being used by algal blooms which were observed during this period. Low levels of total nitrogen $\left(T N=0.68 \mathrm{mg} \cdot \mathrm{L}^{-1}\right)$ were recorded during June. Ammonia values were high for March $\left(0.40 \mathrm{mg} \cdot \mathrm{L}^{-1}\right)$ while in August and October recorded high values $\left(0.11 \mathrm{mg} \cdot \mathrm{L}^{-1}\right.$ and $\left.0.26 \mathrm{mg} \cdot \mathrm{L}^{-1}\right)$. Low values of ammonia were observed during the hot-wet season. Nitrate was low during the hot-wet season with low values being observed in July $\left(0 \mathrm{mg} \cdot \mathrm{L}^{-1}\right)$ but increased from August $\left(0.01 \mathrm{mg} \cdot \mathrm{L}^{-1}\right)$ to October $\left(0.03 \mathrm{mg} \cdot \mathrm{L}^{-1}\right)$. Nitrate was high in March $\left(0.07 \mathrm{mg} \cdot \mathrm{L}^{-1}\right)$ and June $\left(0.04 \mathrm{mg} \cdot \mathrm{L}^{-1}\right)$. Total dissolved solutes (TDS) were in the range $226.7-344.9 \mathrm{mg} \cdot \mathrm{L}^{-1}$ for the study months, with higher values from April to July. Conductivity concentrations increased from April $\left(358 \mu \mathrm{S} \cdot \mathrm{cm}^{-1}\right)$ to June $\left(376 \mu \mathrm{S} \cdot \mathrm{cm}^{-1}\right)$, decreased to a low of $338.4 \mu \mathrm{S} \cdot \mathrm{cm}^{-1}$ in July before increasing to a high to a peak of $433.3 \mu \mathrm{S} \cdot \mathrm{cm}^{-1}$ in October (Table I). The increase 


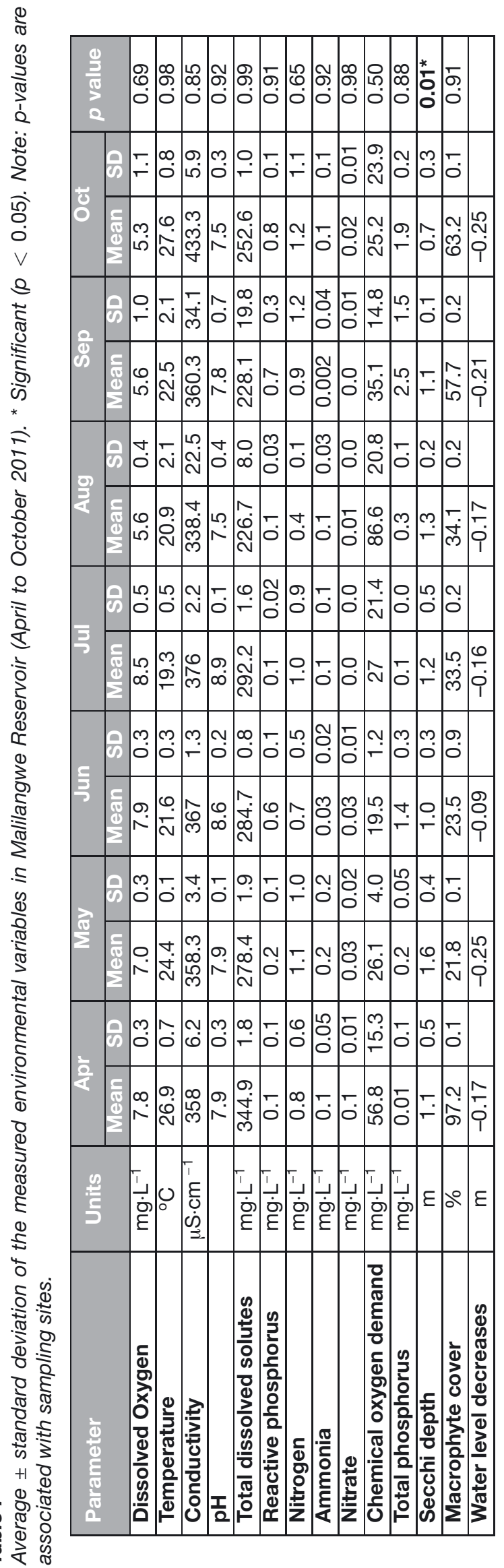


in conductivity could be attributed to water level decreases which induced evaporation-driven concentration of dissolved material in the water.

Macrophyte cover changed with changes in seasons from the dominant emergent macrophytes in the hot-wet season to dominant submerged macrophytes in the hot-dry season. In April, sites 1 and 2 had similar macrophyte species composition namely; Cyperus sp., Ludwigia stolonifera, Phragmites mauritianus, Potamogeton crispus and Schoenoplectus corymbosus. Site 3 had all the species found in site 1 and 2 with the exception of $P$. crispus. Panicum repens and Azolla filiculoides were only recorded in site 4 and 5 respectively plus the above named species excluding $P$. crispus. At sites 1,2 and $3, L$. stolonifera was the most dominant species in terms of distribution and in site 4 and $5, A$. filiculoides and S. corymbosus were the most dominant. During the cool-dry season (May to August 2011), a larger proportion of the littoral zone had no macrophytes growing (>65\%). There was a decline in species number from hot-wet season (7 species) to the cool-dry season (4 species), and the remaining species were A. filiculoides, L. stolonifera, P. mauritianus and P. crispus. Ludwigia stolonifera had the widest distribution occurring at all the study sites, whilst $P$. crispus was less distributed. During the hot-dry season (September to October), six macrophyte species not recorded before were identified namely; Marsilea sp., Ceratophyllum demersum Najas sp., Potamogeton pusillus, Potamogeton tricarinatus and Persicaria decipiens. The dominant macrophyte species at sites 3, 4 and 5 was $C$. demersum, while in site 1 and 2, P. Pusillus and $P$. mauritianus were the most dominant species respectively.

\section{> MACROINVERTEBRATE DIVERSITY}

A total of 16,777 individual macroinvertebrates belonging to 42 families and 10 orders were collected from the sites. The mean relative abundance (\%) of the macroinvertebrates and total number of identified families collected from each sampling site are shown in Table II. More macroinvertebrate families were sampled at sites 1-4 (30-33) than in sites 5. Mollusca constituted $57.71 \%$ of the total sample and other common taxa included the Hemiptera $(27.31 \%)$, Diptera (4.93\%), Arachnida (3.22\%) and Odonata (3.12\%). The most common family taxa were Odonata (9 families), Hemiptera (8) and Mollusca (7) (Table II). There was a notable increase in abundance of the Mollusca group during the cool-dry season.

Macroinvertebrate taxa composition and abundance at the study sites also changed from April to October. Sites 1, 2, 3 and 4 had taxa richness of 32, 33 and 30 respectively, while site 4 and 5 had a richness of 24 and 26, respectively. Sites 1 and 2 had macroinvertebrate families only unique to these sites (Teloganodidae, Pisauridae and Platycnemidae). Sites 1 to 3 had Lymnaeidae, site 2 had Calopterygidae, site 3 had Pyralidae and Hydrophilidae and site 4 had Ancylidae and Sphaeridae which were unique to the sites (Table II).

Site 1 and 2 had almost similar dominance indices (Shannon-Weaver $=1.784$ and 1.750 respectively) and dominance decreased in site 4 to 0.953 before increasing to 1.293 in site 5 (Table II). The Simpson's diversity index for site 1,2 and 3 was $0.754,0.742$ and 0.729 respectively and it decreased to 0.414 in site 4 . Site 5 had a Simpson's diversity index of 0.593 . Evenness for the first three sites (1,2 and 3 ) was similar $(0.277,0.271$ and 0.277 respectively) and decreased for site 4 (0.154). Site 5 had an evenness of 0.201 (Table II). Thus sites closer to the dam not only have a greater number of taxa present, but the individuals in the community are distributed more equitably among these taxa. Using the Hutchenson (1970) criterion for the comparison of the diversity values, site 4 was found to be the most significantly different $(p<0.05)$ from the rest whilst there were no significant differences amongst other sites.

\section{>MACROINVERTEBRATES TAXA RANK DOMINANCE ANALYSIS}

The rank analysis of the 10 most dominant macroinvertebrate families in Malilangwe Reservoir are shown in Table III and Figure 2. Overall, Thiaridae was the most dominant taxa $(n=6389)$ 
Table II

Relative percentage abundances of macroinvertebrates at the sampling sites on the Malilangwe Reservoir for April to October 2011.

\begin{tabular}{|c|c|c|c|c|c|}
\hline \multirow{2}{*}{ Order / Family } & \multicolumn{5}{|c|}{ Site } \\
\hline & $T$ & 2 & 3 & 4 & 5 \\
\hline \multicolumn{6}{|l|}{ Annelida } \\
\hline Hirudinae & 0.84 & 0.23 & 0.46 & 1.47 & 2.01 \\
\hline Oligochaetae & - & - & 1.09 & 1.57 & 1.53 \\
\hline \multicolumn{6}{|l|}{ Arachnida } \\
\hline Hydracarina (Hydrachnellae) & 3.69 & 5.97 & 2.98 & - & 2.65 \\
\hline Lycosidae & 0.24 & 0.03 & - & - & - \\
\hline Tetragnathidae & 0.03 & 0.16 & 0.06 & - & - \\
\hline Pisauridae & 0.03 & 0.03 & - & - & - \\
\hline \multicolumn{6}{|l|}{ Coleoptera } \\
\hline Curculionidae & - & 0.10 & 0.09 & 0.03 & - \\
\hline Dytiscidae & 0.27 & 0.59 & 0.57 & 0.07 & 0.36 \\
\hline Elmidae & 0.19 & 0.20 & 0.29 & 0.16 & 0.08 \\
\hline Hydrophilidae & - & - & 0.03 & - & 0.20 \\
\hline Hydraenidae & 0.14 & 0.36 & 0.09 & - & 0.52 \\
\hline \multicolumn{6}{|l|}{ Diptera } \\
\hline Culicidae & - & - & - & 0.03 & 0.08 \\
\hline Chaoboridae & 7.00 & 6.27 & 3.49 & 2.09 & 1.20 \\
\hline Chironomidae & 0.14 & 0.46 & 0.40 & 1.21 & 1.57 \\
\hline \multicolumn{6}{|l|}{ Ephemeroptera } \\
\hline Baetidae & 1.33 & 2.79 & 0.11 & 0.49 & 0.52 \\
\hline Teloganodidae & 0.03 & 0.03 & - & - & - \\
\hline \multicolumn{6}{|l|}{ Hemiptera } \\
\hline Belostomatidae & 0.68 & 1.18 & 0.86 & 0.13 & 0.32 \\
\hline Corixidae & 9.34 & 11.48 & 8.91 & 6.64 & 13.45 \\
\hline Gerridae & 0.08 & 0.03 & 0.23 & 0.03 & 0.04 \\
\hline Naucoridae & 0.33 & 0.69 & 0.77 & 0.07 & 0.84 \\
\hline Nepidae & 0.38 & 0.62 & 0.14 & 0.03 & 0.12 \\
\hline Notonectidae & 21.55 & 19.85 & 17.50 & 7.07 & 10.76 \\
\hline Pleidae & 0.41 & 0.20 & 0.09 & 0.13 & 0.04 \\
\hline Veliidae & 0.11 & - & - & - & 0.12 \\
\hline \multicolumn{6}{|l|}{ Lepidoptera } \\
\hline Pyralidae & - & - & 0.03 & - & - \\
\hline \multicolumn{6}{|l|}{ Mollusca } \\
\hline Ancylidae & - & - & - & 0.07 & 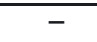 \\
\hline Corbiculidae & 0.03 & 0.07 & 0.74 & 1.34 & 0.04 \\
\hline Lymnaeidae & 8.44 & 1.38 & 6.24 & - & - \\
\hline Physidae & 13.98 & 18.90 & 13.49 & 5.33 & 8.03 \\
\hline Planorbidae & - & - & 3.01 & - & - \\
\hline Thiaridae & 26.25 & 24.02 & 35.11 & 69.21 & 54.15 \\
\hline Sphaeridae & - & - & - & 1.28 & - \\
\hline \multicolumn{6}{|l|}{ Odonata } \\
\hline Aeshnidae & 0.62 & 0.20 & 0.11 & - & 0.04 \\
\hline Calopterygidae & - & 0.39 & - & $\begin{array}{lll}- & \\
\end{array}$ & - \\
\hline Chlorolestidae & 1.14 & 0.85 & 0.49 & - & - \\
\hline Coenagrionidae & 1.95 & 2.40 & 2.18 & 1.01 & 1.12 \\
\hline Gomphidae & 0.11 & 0.13 & 0.14 & 0.16 & 0.16 \\
\hline Lestidae & 0.14 & 0.07 & - & - & - \\
\hline Libellulidae & 0.27 & 0.13 & 0.32 & 0.36 & 0.04 \\
\hline Platycnemidae & 0.08 & 0.16 & - & - & - \\
\hline Protoneuridae & 0.19 & - & $\begin{array}{lll}- & & \\
-\end{array}$ & - & 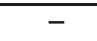 \\
\hline
\end{tabular}


Table II

Continued.

\begin{tabular}{|l|c|c|c|c|c|}
\hline \multirow{2}{*}{ Order / Family } & \multicolumn{5}{|c|}{ Site } \\
\cline { 2 - 6 } & 1 & 2 & 3 & 4 & 5 \\
\hline Trichoptera & & & & & - \\
\hline Hydropsyche & - & 0.03 & - & - & 3140 \\
\hline Total & $\mathbf{3 8 1 4}$ & $\mathbf{3 1 5 2}$ & $\mathbf{3 6 2 2}$ & $\mathbf{3 0 4 9}$ & $\mathbf{3}$ \\
\hline Number of taxa & 32 & 33 & 30 & 24 & 26 \\
\hline Shannon-Weaver index & 1.784 & 1.750 & 1.688 & 0.953 & 1.298 \\
\hline Simpsons index & 0.754 & 0.742 & 0.729 & 0.414 & 0.593 \\
\hline Evenness & 0.277 & 0.271 & 0.277 & 0.154 & 0.201 \\
\hline
\end{tabular}

Table III

Rank abundance of macroinvertebrate taxa for the different study sites (Rel. ab. = relative abundance).

\begin{tabular}{|l|c|c|c|c|c|c|c|c|c|c|}
\hline \multirow{2}{*}{ Family } & \multicolumn{2}{|c|}{ Site 1 } & \multicolumn{2}{c|}{ Site 2 } & \multicolumn{2}{c|}{ Site 3 } & \multicolumn{3}{c|}{ Site 4 } & \multicolumn{3}{c|}{ Site 5 } \\
\cline { 2 - 13 } & Rank & Rel. ab. & Rank & Rel. ab. & Rank & Rel. ab. & Rank & Rel. ab. & Rank & Rel. ab. \\
\hline Physidae & 3 & 515 & 3 & 576 & 3 & 471 & 5 & 63 & 4 & 200 \\
\hline Thiaridae & 1 & 967 & 1 & 732 & 1 & 1226 & 1 & 2115 & 1 & 1349 \\
\hline Coenagrionidae & 8 & 72 & 7 & 73 & 9 & 76 & - & - & 10 & 28 \\
\hline Hydrachnellae & 7 & 136 & 6 & 182 & 8 & 104 & - & - & 5 & 66 \\
\hline Corixidae & 4 & 344 & 4 & 350 & 4 & 311 & 3 & 203 & 2 & 335 \\
\hline Notonectidae & 2 & 794 & 2 & 605 & 2 & 611 & 2 & 216 & 3 & 268 \\
\hline Oligochaetae & - & - & - & - & 10 & 38 & 6 & 48 & 8 & 38 \\
\hline Hirudinae & - & - & - & - & - & - & 7 & 45 & 6 & 50 \\
\hline Chironomidae & - & - & - & - & - & - & 10 & 37 & 7 & 39 \\
\hline Baetidae & 9 & 49 & 8 & 85 & - & - & - & - & - & - \\
\hline Chlorolestidae & 10 & 42 & 10 & 26 & - & - & - & - & - & - \\
\hline Chaoboridae & 6 & 258 & 5 & 191 & 6 & 122 & 4 & 64 & 9 & 30 \\
\hline Lymnaeidae & 5 & 311 & 9 & 42 & 5 & 218 & - & - & - & - \\
\hline Planorbidae & - & - & - & - & 7 & 105 & - & - & - & - \\
\hline Sphaeridae & - & - & - & - & - & - & 9 & 39 & - & - \\
\hline Corbiculidae & - & - & - & - & - & - & 8 & 41 & - & - \\
\hline
\end{tabular}

and the Oligochaeta the least dominant $(n=124)$. For sites 1 and 2 , the 10 dominant families were the same with Thiaridae family being the most dominant will Chlorolestidae was the least dominant. The rank order changed from the fifth family to the ninth for sites 1 and 2. In site 4, Thiaridae was most dominant while Chironomidae was the least dominant. At site 5, Thiaridae was the most dominant with Coenagrionidae being the least dominant. Thiaridae, Physidae, Notonectidae, Corixidae and Chaoboridae were dominant across all the five sites, with the first four being the top four dominant families in the respective sites while Chaoboridae varied in position in the top 10 rank abundance between fifth and nineth (Table III).

\section{>INFLUENCE OF ENVIRONMENTAL FACTORS ON MACROINVERTEBRATE COMMUNITIES}

The results of the RDA (Figure 3) showed that the first two RDA axes accounted for $82.3 \%$ of the taxon-environment relationship whilst also accounting for $16.9 \%$ of the variance in the taxon data (Table IV). Forward selection revealed that from the input environmental variables listed in Table I, macrophyte cover, water levels and conductivity were significant in explaining patterns of occurrence and abundance of macroinvertebrate taxa in Malilangwe (Figure 3). All three factors and all interactions had a significant impact on the macroinvertebrate communities. In April and May, macroinvertebrate communities and abundance were influenced and positively associated by percentage macrophyte cover while the rest of the months (July, August and October) macroinvertebrate communities and abundance were negatively associated and influenced by water level and conductivity. Macroinvertebrate communities and abundance in June and September were less strongly correlated with the three environmental 


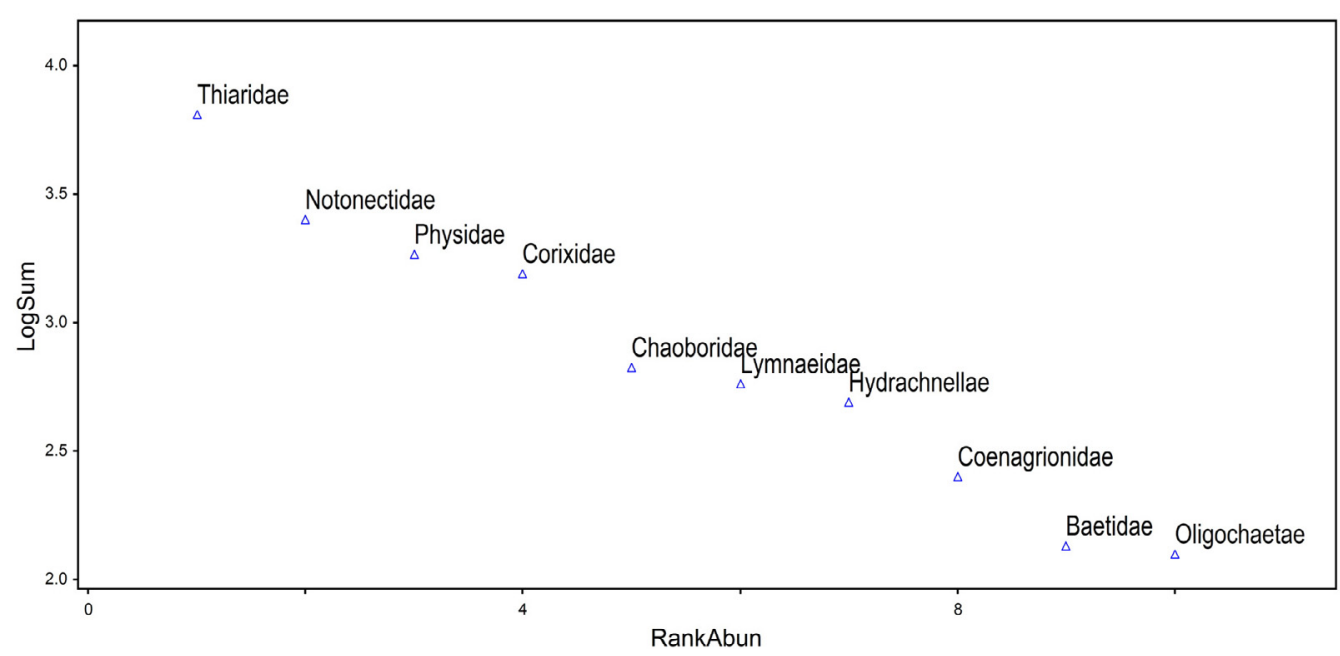

Figure 2

Rank abundance for the 10 dominant macroinvertebrate families in Malilangwe Reservoir (April to October 2011).

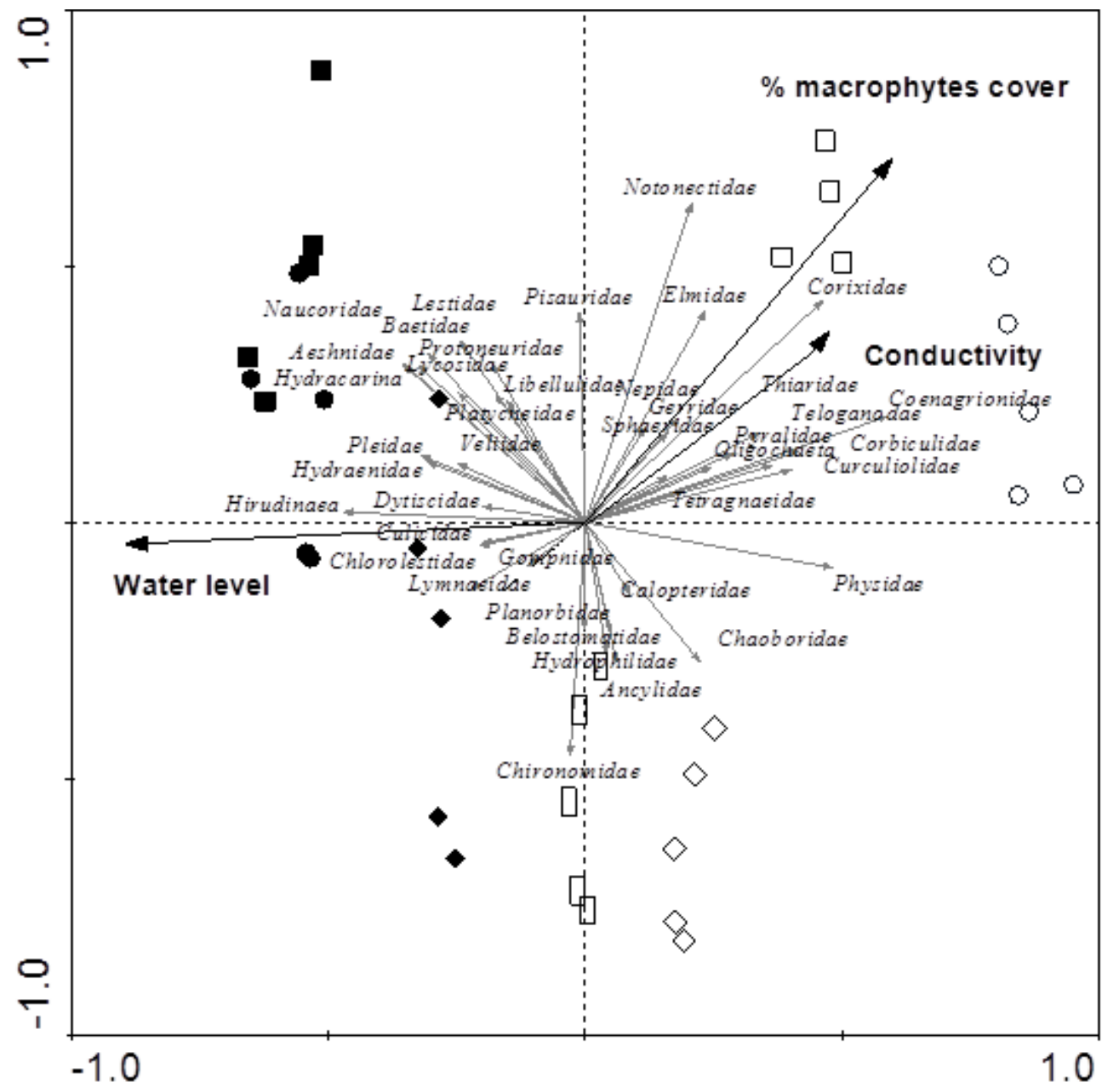

Figure 3

(RDA macroinvertebrate taxa-environmental relations. Significant variables water level, conductivity and macrophyte cover are shown as vectors. $(O=A, \square=M, \diamond=J n, \square=J L, \bullet=A g, \square=S, \bullet=O)$. 


\section{Table IV}

Interactive and individual effects of explanatory variables for macroinvertebrates in Malilangwe Reservoir (April to October 2011).

\begin{tabular}{|l|c|c|c|}
\hline Explanatory variables & $\begin{array}{c}\% \text { species } \\
\text { variation explained }\end{array}$ & F-ratio & $p$ value \\
\hline All significant variables together & & & \\
\hline $\begin{array}{l}\text { Water level } \cap \text { macrophyte } \\
\text { cover } \cap \text { conductivity }\end{array}$ & 16.9 & 2.027 & 0.002 \\
\hline Interactive effects & & & \\
\hline Water level $\cap$ macrophyte cover & 7.1 & 2.399 & 0.002 \\
\hline Water level $\cap$ conductivity & 7.1 & 2.442 & 0.002 \\
\hline Macrophyte cover $\cap$ conductivity & 6.3 & 2.180 & 0.002 \\
\hline Individual effects & & & \\
\hline Conductivity & 5.0 & 1.800 & 0.012 \\
\hline Water level & 7.0 & 2.517 & 0.002 \\
\hline Macrophyte cover & 5.9 & 2.128 & 0.002 \\
\hline
\end{tabular}

parameters (Figure 3). According to the results and RDA analysis (Figure 3), macroinvertebrate communities in the Reservoir were less influenced by most water quality variables with the exception of conductivity which showed a strong environmental gradient and had a structuring effect on macroinvertebrate communities with macrophyte cover and water level fluctuations.

\section{DISCUSSION}

The aim of the study was achieved as highlighted by the results obtained. A total of 42 macroinvertebrate taxa were recorded demonstrating a relatively similar taxa richness when compared to other small Reservoir studies in other regions such as 43 families in Lake Taabo (Kouamé et al., 2011), and 40 families in two lakes of the Paraná River floodplain (de Neiff and Carignan, 1997). Fewer taxa have been recorded from some Reservoirs in Zimbabwe such as 15 taxa in Lake Chivero (Brendonck et al., 2003) and 11 taxa from Fletcher Reservoir (Mwabvu and Sasa, 2009). This could be attributed to the timing, location or many other sampling technique factors and anthropogenic impacts such as sewage discharge in Fletcher Reservoir and Lake Chivero. High taxon coexistence and frequency of occurrence contributed to greater diversity within Malilangwe Reservoir with higher taxon affinities occurring between taxa belonging to different orders possibly suggesting less competition. Nhiwatiwa et al. (2009) showed that resource partitioning among taxa of the different orders has been advanced as a primary reason why such coexistence and high affinities are possible.

Thiaridae and Physidae were the most dominant and abundant Mollusca across all the study sites, especially the Thiaridae family group. Both families (Thiaridae and Physidae) dominance may be attributed to the competitive advantage they have over the other snails of rapidly increasing their populations (Pointier et al., 1989; Kouamé et al., 2011).

Water level of the Reservoir was found to be a relevant and important ecologically variable for macroinvertebrate communities through increasing niche separation, thus allowing more taxa to coexist at higher abundances (Nhiwatiwa et al., 2009). Changes in water levels also affected environmental variables such as macrophyte cover around the Reservoir. During the hot-wet season there was high abundance of macrophyte vegetation in the littoral zone and water level was high before dropping as the seasons changed. These observed changes in the macroinvertebrate communities, might explain the differences in taxon richness and abundance for the study sites. The differences in taxa composition, dominance and abundance among the sites indicated that the macroinvertebrate fauna and the suitability of the habitats maybe strongly influenced by local environmental parameters.

The Simpson's and Shannon-Weaver diversity indices also show that if the macroinvertebrates mostly in sites 1, 2 and 3 should suffer a disturbance, most of the taxa are abundant enough to survive such a disturbance such as macrophyte cover decreases, water 
level fluctuations and increase or decrease in conductivity depending on the magnitude of the disturbance. If the disturbance is small enough, according to the intermediate disturbance hypothesis the diversity of species will be expected to increase in the reservoir (Brown and Lomolino, 1998). Typically the value of the Shannon-Weaver index ranges from 0.953 to 2.19. The maximum index takes its maximum when species richness increases (Brown and Lomolino, 1998). The data for the five sites indicates that they do not have the same taxa richness and abundance hence they are not even (similar or equitable). Therefore, it is seen that sites 1, 2 and 3 has higher diversity (taxa richness and abundance) than sites 4 and 5 maybe due to the former having a better macrophyte area cover. It is important to note that the use of suprageneric taxa abundances in the estimates of the values of diversity is debatable, because the values tend to be underestimated (O'Donnell et al., 1995). Therefore, these values need to be treated with caution although they provide a useful comparative measure. Different levels of disturbance as highlighted above have different effects on macroinvertebrate diversity and if a water manager's goal is to preserve biodiversity in a given water system, he needs to be able to understand how diversity is impacted by different management strategies. Diversity indices provide more information than simply the number of species present, that is, they account for some species being rare and others being common hence they serve as valuable tools that enable biologists and water managers to quantify diversity in a community and describe its numerical structure (Brown and Lomolino, 1998).

Studies by Mwabvu and Sasa (2009) also showed a positive correlation between Physidae (Bulinus africanus) and conductivity $(r=0.56)$ while Efitre et al. (2001) reported that the Uganda lakes with higher conductivity and $\mathrm{pH}$ showed greater taxon richness and abundance of Mollusca. Therefore, high conductivity levels could have had an effect on Mollusca diversity in the Malilangwe Reservoir as it has been shown to be great importance for Mollusca shells (Mwabvu and Sasa, 2009).

Macrophyte cover was also identified as an important habitat variable influencing macroinvertebrate community in Malilangwe Reservoir. Our results indicate that with decrease in macrophyte cover, taxon diversity increased but the abundance of each individual family decreased. Macrophyte cover is of great importance as a refuge for macroinvertebrate taxa from predation, offer a substrate for living on and also for laying eggs in water medium (Amakye, 2001; Kratzer, 2002). However, our findings are similar to findings by Mwabvu and Sasa (2009) who observed the same situation in Fletcher Reservoir. Kovalenko et al. (2010) showed that the abundance of certain macrophytes could explain a small proportion of variability in macroinvertebrate communities. This was consistent with our study Reservoir, as a decline in macrophyte cover and abundance due to drawdown resulted in changes in macroinvertebrate communities, abundance and distribution. Kratzer (2002) studies in the Okefenokee Swamp showed that macrophyte cover changes and abundances affected macroinvertebrate communities and distribution. The low richness observed in site 4 and 5 could be due to less macrophyte cover which is used as refugia by macroinvertebrates.

The findings of the study have shown that differences in richness, abundance and distribution of macroinvertebrates in the Malilangwe Reservoir are influenced by hydrological regimes and environmental factors associated with strong gradients. Macroinvertebrates are highly adaptable to a broad range of ecological conditions hence only strong environmental gradients can have a structuring effect on their communities (Lounaci et al., 2000; Chakona et al., 2009; Nhiwatiwa, 2009). Therefore, the knowledge of the relationships between macroinvertebrates and their environment is of crucial importance in the understanding of the functioning of ecosystems.

\section{ACKNOWLEDGEMENTS}

This research was part of the MSc work of Tatenda Dalu and was made possible through the financial support of the German Academic Exchange Services (DAAD - A/10/02914) and Malilangwe Trust Research Grant. Special thanks go to Lenin Chari, Philemon Chivambu, Patrick Mutizamhepo, Clemence Chakuya, Pandeni Chitimela and Pamushana guides who 
assisted during the field program. Our appreciation also goes to Elizabeth Munyoro, Edwin Zingwe and the technical staff of the Department of Biological Sciences, University of Zimbabwe, for all their technical support during the study.

\section{REFERENCES}

Albertoni E.F., Prellvit L.J. and Palma-Silva C., 2007. Macroinvertebrate fauna associated with Pistia stratiotes and Nymphoides indica in subtropical lakes (south Brazil). Braz. J. Biol., 67, 499-507.

Amakye J.S., 2001. Some observations on macro-invertebrate benthos of Lake Volta at Yeji Area (Stratum VII) Thirty years after impoundment. West Afr. J. Appl. Ecol., 2, 91-103.

Bailey R.C., Norris R.H. and Reynoldson T.B., 2001. Taxonomic resolution of benthic macroinvertebrate communities in bioassessments. J. North Amer. Benthol. Soc., 20, 280-286.

Barson M., Mulonga A. and Nhiwatiwa T., 2008. Investigation of a parasitic outbreak of Lernaea cyprinacea Linnaeus (Crustacea: Copepoda) in fish from Zimbabwe. Afr. J. Zool., 43, 175-183.

Begg G.W., 1970. Limnological observations on Lake Kariba during 1967 with emphasis on some special features. Limnol. Oceanogr., 15, 776-778.

Bond N.R., Lake P.S. and Arthington A.H., 2008. The impacts of drought on freshwater ecosystems: an Australian perspective. Hydrobiologia, 600, 3-16.

Brendonck L., Maes J., Rommens W., Dekeza N., Nhiwatiwa T., Barson M., Callebaut V., Phiri C., Moreau K., Gratwicke B., Stevens M., Alyn N., Holsters E., Ollevier F., Marshall BE., 2003. The impact of water hyacinth (Eichhornia crassipes) in a eutrophic subtropical impoundment (Lake Chivero, Zimbabwe). II. Species diversity. Arch. Hydrobiol., 158, 389-405.

Brown J.H. and Lomolino M.V., 1998. Biogeography, 2nd edition, Sinauer Associates, United States, $5-45$.

Chakona A., Phiri C., Chinamaringa T. and Muller N., 2009. Changes in biota along a dry-land river in northwestern Zimbabwe: declines and improvements in river health related to land use. Aquat. Ecol., 43, 1095-1106.

Clegg B.W., 2010. Habitat and diet selection by the African elephant at the landscape level: a functional integration of multi-scale foraging processes, Ph.D. Thesis, University of the Witwatersrand, South Africa.

Curtis B.A., 1991. Freshwater macro-invertebrates of Namibia. Madoqua, 17, 163-187.

Davy J., 2005. Nature conservation experiential year at Malilangwe conservation trust Zimbabwe. Course 201123, ND nature conservation, experiential learning, Cape Peninsula University of technology, 6-9.

De Neiff P.R. and Carignan A., 1997. Macroinvertebrates on Eichhornia crassipes roots in two lakes of the Paraná River floodplain. Hydrobiologia, 345, 185-196.

Efitre M.J., Chapman L.J. and Makanga B., 2001. The inshore benthic macro invertebrates of Lake Nabugabo, Uganda: Seasonal and spatial patterns. Afr. J. Zool., 36, 205-216.

Gasith A. and Gafny S., 1990. Effects of water level fluctuation on the structure and function of the littoral zone. In: Tilzer M.M. and Serruya C. (eds.), Large Lakes: Ecological Structure and Function, Springer-Verlag, Berlin, 156-171.

Gerber A. and Gabriel M.J.M., 2002a. Aquatic invertebrates of South African rivers: Field guide. Resource Quality Services, Department of Water Affairs and Forestry, Pretoria, South Africa, $150 \mathrm{p}$

Gerber A. and Gabriel M.J.M., 2002b. Aquatic invertebrates of South African rivers: Illustrations. Resource Quality Services, Department of Water Affairs and Forestry, Pretoria, South Africa, 1-15.

Gooderham J. and Tsyrlin E., 2002. The Waterbug Book: A Guide to the Freshwater Macroinvertebrates of Temperate Australia. CSIRO Publishing, Collingwood, 13-116.

Hann B.J., 1995. Invertebrate associations with submersed aquatic plants in a prairie wetland. UFS (Delta Marsh) Annual Report, 30, 78-85.

Kelly R.D. and Walker B.H., 1976. The effects of different forms of land use on the ecology of a semi-arid region in south-eastern Rhodesia. J. Ecol., 64, 553-576.

Kouamé M.K., Dietoa M.Y., Edia E.O., Da Costa S.K., Ouattara A. and Gourène G., 2011. Macroinvertebrate communities associated with macrophyte habitats in a tropical man-made lake (Lake Taabo, Côte d'Ivoire). Knowl. Managt. Aquatic Ecosyst., 400, 1-8. 
Kovalenko K.E., Dibble E.D. and Slade J.G., 2010. Community effects of invasive macrophyte control: role of invasive plant abundance and habitat complexity. J. Appl. Ecol., 47, 318-328.

Kratzer E.B., 2002. Temporal and spatial variation of wetland macroinvertebrates of the Okefenokee swamp, MSc thesis, Athens, Georgia.

Lounaci A., Brosse S., Thomas A. and Lek S., 2000. Abundance, diversity and community structure of macroinvertebrates in an Algerian stream: The Sébaou wadi. Ann. Limnol., 36, 123-133.

Machena C. and Kautsky N., 1989. A quantitative diving survey of benthic vegetation and fauna in Lake Kariba, a tropical man-made lake. Fresh. Biol., 19, 1-14.

McCune B. and Mefford M.J., 2006. PC-ORD: Multivariate Analysis of Ecological Data. Version 5.10. MjM Software, Gleneden Beach, Oregon, USA.

Mhlanga L. and Siziba N., 2006. The association between invertebrates and macrophytes in a tropical reservoir, Lake Kariba, Zimbabwe; a preliminary survey. Afr. J. Aquat. Sci., 31, 271-274.

Mwabvu T. and Sasa A., 2009. The influence of environmental parameters on the abundance, distribution and species composition of macro-invertebrates in Fletcher Reservoir, Zimbabwe. Afr. J. Ecol., 47, 502-508.

Nhiwatiwa T., 2009. The ecology of temporary pools in the south-eastern lowveld of Zimbabwe, Ph.D. Thesis, Katholieke Universiteit Leuven.

Nhiwatiwa T., de Bie T., Vervaeke B., Barson M., Stevens M., Vanhove M.P.M. and Brendonck L., 2009. Invertebrate communities in dry-season pools of a large subtropical river: patterns and processes. Hydrobiologia, 630, 169-186.

Phiri C., Chakona A. and Day J.A., 2011a. The effect of plant density on epiphytic macroinvertebrates associated with a submerged macrophyte, Lagarosiphon ilicifolius Obermeyer in Lake Kariba, Zimbabwe. Afr. J. Aquat. Sci., 36, 289-297.

Phiri C., Chakona A. and Day J.A., 2011b. Aquatic insects associated with two morphologically different submerged macrophytes, Lagarosiphon ilicifolius and Vallisneria aethiopica in small fishless ponds. Aquat. Ecol., 45, 405-416.

Pointier J.P., Guyard A. and Mosser A., 1989. Biological control of Biomphalaria glabrata and B. straminea by the competitor snail Thiara tuberculata in a transmission site of schistosomiasis in Martinique, French West Indies. Ann. Trop. Med. Parasitol., 83, 263-269.

Rocha-Ramirez A., Ramirez-Rojas A., Chavez-Lopez R. and Alcocer J. 2007., Invertebrate assemblages associated with root masses of Eichhornia crassipes (Mart.) Solms-Laubach 1883 in the Alvarado Lagoonal System, Veracruz, Mexico. Aquat. Ecol., 41, 319-333.

Shannon C.E. and Weaver W., 1949. The Mathematical Theory of Communications. University of Ilinois Press, Urbana.

Simpson E.H., 1949. Measurement of diversity. Nature, 163, 688-674.

Skoroszewski R. and de Moor F., 1999. Macroinvertebrates. Consulting Services for the Establishment and Monitoring of the Instream Flow Requirements for River Courses Downstream of LHWP Dams, Report No. LHDA 648-F-17, 10-14.

Systat., 2007. Mystat: A student version of Systat 32-bit UNICODE English. Version 12.02.00. SYSTAT Software, Inc.

Takhelmayum K. and Gupta S., 2011. Distribution of aquatic insects in phumdis (floating island) of Loktak Lake, Manipur, northeastern India. J. Threatened Taxa, 3, 1856-1861.

Ter Braak C.J.F., 2002. Canoco version 4.5. Biometrics - quantitative methods in the life and earth sciences. Plant Research International, Wageningen University and Research Centre, Wageningen.

Traill L., 2003. Habitat partitioning and an assessment of habitat suitability using present data of a large herbivore community on the Zimbabwean private wildlife reserve, Master of Forestry thesis. University of Stellenbosch, 25-29.

O'Donnell A.G., Goodfellow M. and Hawksworth D.L., 1995. Theoretical and practical aspects of the quantification of biodiversity among microorganisms. In: Hawksworth D.L. (ed.), Biodiversity measurement and estimation. Royal Society/Chapman and Hall, Oxford. 69-71.

Zohary T. and Ostrovsky I., 2011. Ecological impacts of excessive water level fluctuations in stratified freshwater lakes. Inland Waters, 1, 47-59. 